\title{
Alosetron Hydrochloride
}

National Cancer Institute

\section{Source}

National Cancer Institute. Alosetron Hydrochloride. NCI Thesaurus. Code C47386.

The hydrochloride salt form of alosetron, a potent and selective 5-HT3 receptor antagonist. Alosetron blocks the actions of serotonin at 5-HT3 sites in the peripheral nervous system, particularly on enteric and nociceptive sensory neurons, thereby affecting the regulation of visceral pain, decreasing gastrointestinal contraction and motility, and decreasing gastrointestinal secretions. This agent is used to treat diarrheapredominant irritable bowel syndrome in women. 